\title{
Inhibition of Proliferation of Human Prostate Carcinoma Cell, PC3 by Bauhinia racemosa Lam. via Induction of Apoptosis
}

\author{
Md Azizur Rahman ${ }^{1, *}$, Juber Akhtar', Sahabjada², Md Arshad², Md Mujahid ${ }^{1}$ \\ 1'Department of Pharmacy, Herbal Bioactive Research Laboratory, Integral University, Lucknow, Uttar Pradesh, INDIA. \\ 2Department of Zoology, Molecular Endocrinology Lab, University of Lucknow, Lucknow, Uttar Pradesh, INDIA.
}

\begin{abstract}
Background: Prostate cancer is the second foremost cause of cancer death in Western males, the progression of which may be a consequence of defect in apoptotic machinery. Objective: Thus, aim of the study was designed to investigate inhibition of proliferation of human prostate carcinoma cell line, PC3 by Methanolic extract of Bauhinia racemosa Lam (MEBR). Methods: MTT assay was performed to evaluate antiproliferative effect of MEBR on prostate carcinoma cell line while DAPI and DCFH-DA staining studies were performed to investigate the underlying mechanism in antiproliferative effect of MEBR. Results: Total flavonoid content in MEBR was found to be $868 \mathrm{mg}$ QE/g dried extract. MEBR exposure to PC3 cells significantly $(p<0.001)$ increased the cytotoxicity in a concentration dependent manner. The percent cytotoxicity data indicates that exposure of PC3 cells to 25 and $50 \mu \mathrm{g} / \mathrm{ml}$ of MEBR, cytotoxicity was $15.42 \%$ and $36.67 \%$ respectively as compared to control, which further increased to $56.82 \%$ and $78.04 \%$ $(p<0.001)$ at $75 \mu \mathrm{g} / \mathrm{ml}$ and $100 \mu \mathrm{g} / \mathrm{ml}$ respectively. $\mathrm{IC}_{50}$ value was found to be $66.85 \mu \mathrm{g} /$ $\mathrm{ml}$ of the extract MEBR. MEBR induced significant $(p<0.001)$ nuclear condensation in a concentration dependent manner depicting the induction of apoptosis in PC3 cells. MEBR elevated the significant ROS activity level and fluorescence intensity in a concentration dependent manner as compared to control in PC3 cells exposed to MEBR. Conclusion: MEBR possesses antiproliferative activity and leads to PC3 cell death via induction of apoptosis mediated through excessive ROS generation. Hence, the extract MEBR may be potentially precious for application in chemotherapeutic drug developments for prostate cancer..
\end{abstract}

Key words: Prostate cancer, PC3, Bauhinia racemosa, Apoptosis, Reactive oxygen species.

\section{INTRODUCTION}

Nowadays, cancer has become the foremost cause of death in human beings where prostate cancer is the most frequently diagnosed one and second foremost cause of cancer death in males of Western countries. ${ }^{1,2}$ Chemotherapy is mainly employed clinically for the management and treatment of such cancer. $^{3}$ Thus, scientists are struggling to find effective clinical treatment of such cancer and are investigating for novel anticancer agents from all sources. The investigation of anticancer agents from plant kingdom has been greatly emphasized. ${ }^{4}$
The plant Baubinia racemosa Lam. belonging to the family Caesalpiniaceae is a small deciduous tree used in the indigenous system of medicine and is very common in foothills upto $1000 \mathrm{~m}$ in India and Srilanka. ${ }^{5,6}$ It is commonly named as Mountain Ebony (English), Kachnal/ Kanchanara/ Sonpatta (Hindi), Gul-e-anehnal (Urdu) and Sona/ Sonpatta or Apta (Marathi). ${ }^{7}$ The various parts of the plant viz., stem bark, leaves and roots are practiced in various indigenous systems of medicine and popular among the various ethnic groups in India for the
Submission Date: 18-09-2018; Revision Date: 28-12-2018; Accepted Date: 07-03-2019

DOI: 10.5530/ijper.53.3.84 Correspondence: Dr. Md. Azizur Rahman, Associate Professor (Jr.), Department of Pharmacy, Herbal Bioactive Research Laboratory Integral University, Lucknow, Uttar Pradesh226026, INDIA.

Phone: : +91 8896510421

E-mail: marahman@iul.ac.in

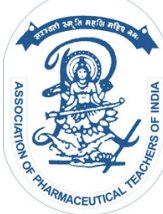

www.ijper.org 
cure of variety of ailments. ${ }^{6,7}$ The bark of $B$. racemosa is reported to have antifilarial, abortifacient, anthelmintic, analgesic, antipyretic, antimalarial, anti-ulcerogenic, hepatoprotective and various other pharmacological activities. ${ }^{7,8}$ Previously reported phytochemical constituents from its bark are octacosane, $\beta$-amyrin, $\beta$-sitosterol, triterpenoids and sterols. ${ }^{7,9}$ Thus, in order to investigate the antiproliferative effect of Methanolic extract of $B$. racemosa (MEBR) on prostate cancer cell line and to elucidate the underlying mechanism of cancer prevention, MTT assay and assessment of apoptosis induction were carried out.

\section{MATERIALS AND METHODS}

\section{Authentication of Plant Material}

B. racemosa Lam bark collected from Chittoor of Andhra Pradesh was authenticated by the botanist, authentication office, Sri Venkateswara University, Tirupati, India (Authentication no.: SVUBH/LE/1876).

\section{Preparation of Drug Extract}

Collected B. racemosa Lam bark was shade dried, roughly powdered and extracted by methanol using Soxhlet extractor to get the extract, MEBR. Appearance of colorless methanol in the siphon tube of extractor was considered as the termination of Soxhlet extraction. The obtained extract was filtered while hot and then concentrated to dryness in a rotary evaporator (Buchi Rotavapor-R, Labco, India) under controlled temperature and pressure. ${ }^{10}$

\section{Cell Line Culture}

PC3, the human prostate carcinoma cell line obtained from National Centre for Cell Sciences (NCCS), Pune, India was cultured in Dulbecco's modified Eagle's medium (DMEM, Himedia) with added 10\% (v/v) fetal calf serum (Himedia), $0.1 \mathrm{mM}$ non-essential amino acids (NEAA), $1 \mathrm{mM}$ sodium pyruvate, $1 \%$ antibiotic solutions, $2 \mathrm{mM} \mathrm{L}$-glutamine and $1.5 \mathrm{~g} / 1$ sodium bicarbonate. The cells were grown in $\mathrm{CO}_{2}$ incubator (Excella ECO170, New Brunswick) maintained at $37^{\circ} \mathrm{C}$ with $5 \% \mathrm{CO}_{2}$ in humidified air.

\section{Determination of Total Flavonoid Content}

One millilitre of $1 \mathrm{mg} / \mathrm{ml}$ MEBR solution was added into a tube containing $2 \mathrm{ml}$ of double-distilled water. Then, $3 \mathrm{ml}$ of $0.5 \% \mathrm{NaNO}_{2}, 0.30 \mathrm{ml}$ of $10 \% \mathrm{AlCl}_{3}$ and $2 \mathrm{ml}$ of $1 \mathrm{M} \mathrm{NaOH}$ were added to it at 0,5 and 6 min sequentially. Volume was make upto $10 \mathrm{ml}$ with doubledistilled water, thoroughly mixed and allowed to stand for $15 \mathrm{~min}$. The absorbance was recorded at the maxi- mum wavelength of $510 \mathrm{~nm}$ using UV-spectrophotometer (Shimadzu, Japan). Flavonoid content was estimated from quercetin standard curve. All the determinations were performed three times. ${ }^{11}$

\section{MTT Assay for Cytotoxicity in PC3 Cells}

The $1 \times 10^{4}$ PC 3 cells per well were seeded in $100 \mu \mathrm{L}$ complete medium in the wells of the 96-well culture plate for $24 \mathrm{~h}$ in $\mathrm{CO}_{2}$ incubator. Different concentrations of $\operatorname{MEBR}(25,50,75,100 \mu \mathrm{g} / \mathrm{ml})$ prepared directly in the medium were added to the wells in triplicate as per experimental design. After $21 \mathrm{~h}$ of treatment, $10 \mu \mathrm{L}$ of methyl-thiazolyl-tetrazolium dye (MTT, Himedia) solution was added in the wells and the plate was further incubated for another $3 \mathrm{~h}$ in $\mathrm{CO}_{2}$ incubator. Then, the supernatant was discarded and $100 \mu \mathrm{L}$ of dimethyl sulphoxide (DMSO) was added to each well for $10 \mathrm{~min}$ at $37^{\circ} \mathrm{C}$. The absorbance was read at maximum wavelength of $540 \mathrm{~nm}$ by a microplate Elisa reader (BIORAD-680) using the wells without MEBR as control. The percent cytotoxicity was calculated according to the equation [\% cytotoxicity $\left.=\left\{1-\left(A_{\mathrm{T}} / A_{\mathrm{C}}\right)\right\} \times 100\right]$, where $A_{\mathrm{C}}$ is the absorbance value of the control and $A_{\mathrm{T}}$ is the absorbance value of treated and concentration lethal to $50 \%$ of the cells $\left(\mathrm{IC}_{50}\right)$ was found out. ${ }^{12}$

\section{Cell Morphology Analysis}

The effect of MEBR was analyzed for morphological changes in the cultured cells. The $1 \times 10^{4} \mathrm{PC} 3$ cells per well were seeded in $100 \mu \mathrm{L}$ complete medium in the wells of the 96-well culture plate for $24 \mathrm{~h}$ in $\mathrm{CO}_{2}$ incubator. Then, the cells were exposed to different concentrations of MEBR $(25,50,75,100 \mu \mathrm{g} / \mathrm{ml})$ prepared directly in the medium for $24 \mathrm{~h}$. The cellular morphology was observed by inverted phase contrast microscopy (Nikon Eclipse Ti-S, Japan). ${ }^{12}$

\section{DAPI Staining for Analysis of Apoptosis Induction}

The $1 \times 10^{4}$ PC 3 cells per well were seeded in $100 \mu \mathrm{L}$ complete medium in the wells of the culture plate for $24 \mathrm{~h}$ in $\mathrm{CO}_{2}$ incubator. The cells in triplicate were then exposed to two different concentrations of MEBR (25 and $75 \mu \mathrm{g} / \mathrm{ml}$ ) for $12 \mathrm{~h}$. Then, extract plus media was removed, cells were washed with Phosphate buffered saline (PBS) and fixed in 4\% paraformaldehyde for $10 \mathrm{~min}$. Subsequently, the cells were permealized with the buffer $(0.5 \%$ Triton X-100, Merck, India and 3\% paraformaldehyde) and stained with $50 \mu \mathrm{L}$ of fluorescent nuclear dye 4',6-diamidino-2-phenylindole (DAPI, Himedia). After $1 \mathrm{~h}$, the cells were observed for the fluorescence intensity and apoptotic cells. Images were taken and number of cells was counted by using fluo- 
rescent microscope (Nikon Eclipse Ti-S, Japan). The percent apoptotic cells was calculated according to the equation

$$
\% \text { apoptotic cell }=\frac{\{(\text { apoptotic cells }+ \text { late apoptotic cells })}{(\text { total no of cells })\}} \times 100
$$

\section{DCFH-DA Staining for Intracellular ROS Activity Level Analysis}

Microscopic fluorescence imaging and quantitative fluorometric analysis were used to analyze generation of Reactive oxygen species (ROS) in PC3 cells exposed to MEBR. The $1 \times 10^{4}$ cells per well were seeded in culture plates, kept in $\mathrm{CO}_{2}$ incubator for $24 \mathrm{~h}$ and then exposed to two different concentrations of MEBR (25 and $75 \mu \mathrm{g} / \mathrm{ml}$ ) for $12 \mathrm{~h}$. Then, mixture was again incubated with $10 \mathrm{mM}$ 2,7-dichlorodihydrofluorescein diacetate stain (DCFH-DA, Sigma-Aldrich, USA) for 30 min in $\mathrm{CO}_{2}$ incubator. The mixture was aspirated and replaced by $200 \mu \mathrm{L}$ of PBS in the wells. The plates were kept on a shaker for $10 \mathrm{~min}$ at room temperature in the dark. Intracellular fluorescence was analyzed by an inverted fluorescence microscope. For quantitative fluo-

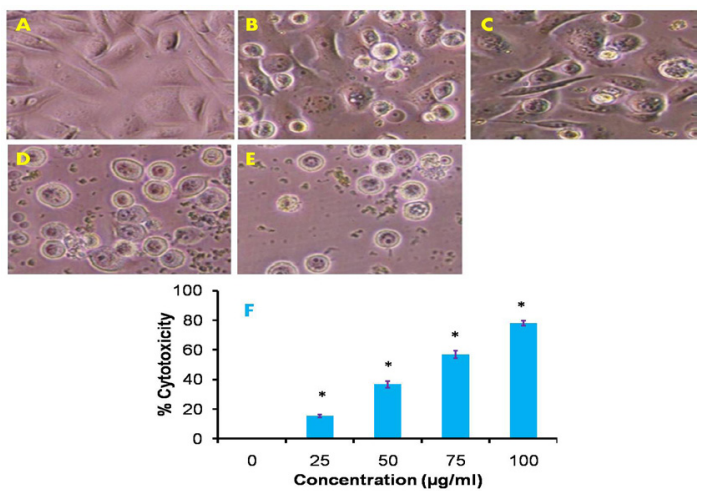

Figure 1: Morphological view (A-E) and percent cytotoxicity (F) of PC3 cells exposed to grading concentrations $(0-100 \mu \mathrm{g} / \mathrm{ml})$ of methanolic extract of $B$. racemosa bark, MEBR as measured by MTT assay at $24 \mathrm{~h}$. rometric analysis, $1 \times 10^{4}$ cells per well were re-seeded in black bottomed culture plate and kept in $\mathrm{CO}_{2}$ incubator for $24 \mathrm{~h}$. Cells in triplicate were then exposed to two different concentrations of MEBR (25 and $75 \mu \mathrm{g} /$ $\mathrm{ml})$ for $12 \mathrm{~h}$. Then, cells were again incubated with 10 $\mathrm{mM}$ DCFH-DA for $30 \mathrm{~min}$ in $\mathrm{CO}_{2}$ incubator. Fluorescence intensity was measured with a multi-well microplate reader (Synergy H1 hybrid multi-mode microplate reader, BioTek) at wavelength of $528 \mathrm{~nm}$ relative to the control. Increased intensity of intracellular fluorescence was indicative of increased intracellular ROS activity level. ${ }^{14}$

\section{Statistical Analysis}

All the data were expressed as Mean \pm Standard deviation (SD). Statistical significance was determined by one-way ANOVA using the GraphPad Prism program. Value of $P<0.05$ was considered statistically significant.

\section{RESULTS}

\section{Determination of Total Flavonoid Content}

Total flavonoid content in MEBR was found to be 868 $\mathrm{mg} \mathrm{QE} / \mathrm{g}$ dried extract where QE denotes to quercetin equivalent (Table 1).

\section{MTT Assay for Cytotoxicity in PC3 Cells and Cell Morphological Analysis}

MTT assay for cytotoxicity in PC3 cells demonstrated the antiproliferative effect of extract MEBR in prostate carcinoma, PC3 cell line. It was found that morphological shapes of the cells were drastically changed in concentration dependent manner. Images (Figure 1A, $1 \mathrm{~B}, 1 \mathrm{C}, 1 \mathrm{D}$ and $1 \mathrm{E})$ revealed that cells were detached themselves from the well surface and changed to round shape in the groups exposed to MEBR. Significant cytotoxicity characterized by deformation of cell bodies, cel-

\begin{tabular}{|c|c|c|c|c|c|c|}
\hline & \multirow{2}{*}{$\begin{array}{c}\text { Conc ( } \mu \mathrm{g} / \\
\mathrm{ml})\end{array}$} & \multicolumn{4}{|c|}{ Observed absorbance } & \multirow{2}{*}{$\begin{array}{l}\text { Flavonoid } \\
\text { content (mg } \\
\text { QE/g extract) }\end{array}$} \\
\hline & & $1^{\text {st }}$ & $2^{\text {nd }}$ & $3^{\text {rd }}$ & Mean \pm SD & \\
\hline \multirow[t]{6}{*}{ Quercetin } & 50 & 0.18 & 0.18 & 0.19 & $0.18 \pm 0.01$ & \\
\hline & 100 & 0.27 & 0.28 & 0.29 & $0.28 \pm 0.01$ & \\
\hline & 200 & 0.45 & 0.47 & 0.50 & $0.47 \pm 0.02$ & \\
\hline & 300 & 0.70 & 0.72 & 0.73 & $0.72 \pm 0.02$ & \\
\hline & 400 & 0.87 & 0.88 & 0.89 & $0.88 \pm 0.01$ & \\
\hline & 500 & 0.99 & 0.99 & 0.99 & $0.99 \pm 0.01$ & \\
\hline MEBR & 500 & 0.54 & 0.53 & 0.54 & $0.54 \pm 0.01$ & 868 \\
\hline
\end{tabular}



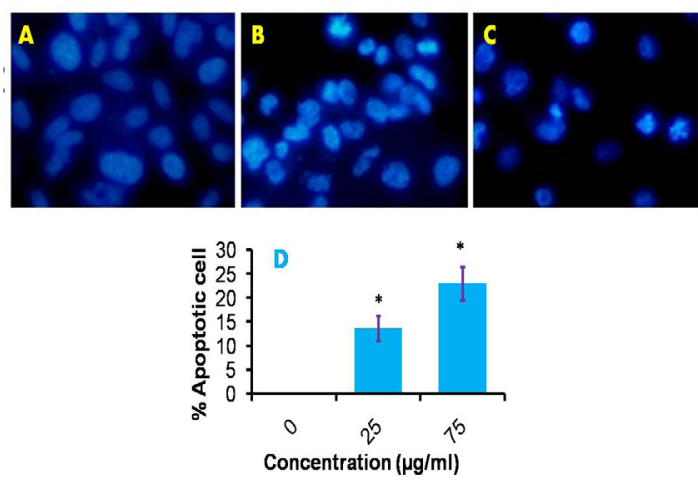

Figure 2: Apoptosis (A-C) and percent apoptotic cells (chromatin condensation) (D) of PC3 cells exposed to grading concentrations of methanolic extract of $B$. racemosa bark, MEBR $(0-75 \mu \mathrm{g} / \mathrm{ml})$ as measured by DAPI staining at $12 \mathrm{~h}$.

lular shrinkage and surface detachment was observed in the groups exposed to MEBR at higher concentrations. MEBR exposure to PC3 cells significantly $(p<0.001)$ increased the cytotoxicity in a concentration dependent manner. The percent cytotoxicity data indicates that exposure of PC3 cells to $25 \mu \mathrm{g} / \mathrm{ml}$ and $50 \mu \mathrm{g} / \mathrm{ml}$ of MEBR lead to cytotoxicity to $15.42 \%$ and $36.67 \%$ respectively as compared to control, which further significantly $(p<0.001)$ increased to $56.82 \%$ and $78.04 \%$ at $75 \mu \mathrm{g} / \mathrm{ml}$ and $100 \mu \mathrm{g} / \mathrm{ml}$ respectively. From the graph obtained (Figure 1.F), $\mathrm{IC}_{50}$ value was found to be 66.85 $\mu \mathrm{g} / \mathrm{ml}$ of the extract MEBR.

\section{DAPI Staining for Analysis of Apoptosis Induction}

Images (Figure 2A, 2B and 2C) depict the details of MEBR induced apoptosis observed by using fluorescent DAPI staining. The cells with condensed and fragmented nuclei were regarded as apoptotic cells. As observed from the graph (Figure 2D), MEBR induced significant $(p<0.001)$ nuclear condensation in a concentration dependent manner depicting the induction of apoptosis in PC3 cells.

\section{DCFH-DA Staining for Intracellular ROS Activity Level Analysis}

Fluorescent images (Figure 3A, 3B and 3C) of PC3 cells stained with DCFH-DA depicted the effect of MEBRinduced intracellular ROS activity level. The supplementary images and the graph of percent DCF-fluorescence (Figure 3D) suggested that MEBR elevated the significant ROS activity level and fluorescence intensity in a concentration dependent manner as compared to control in PC3 cells exposed to MEBR. It indicates that increased ROS activity level in PC3 cells is involved in the induction of apoptosis.
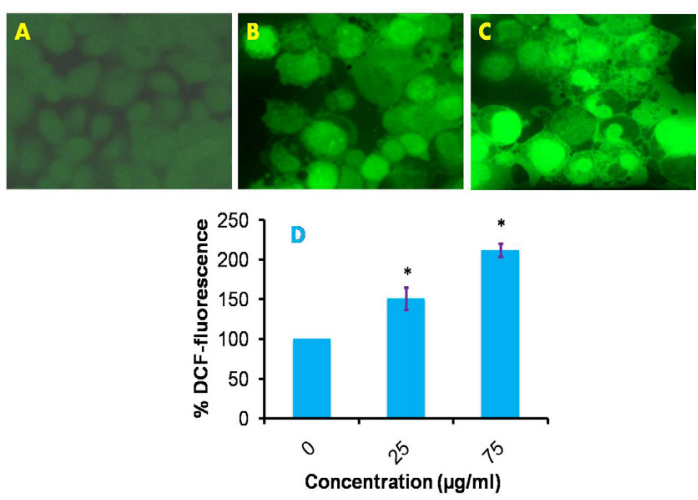

Figure 3: Intracellular ROS activity level (A-C) and percent DCF-fluorescence (D) in PC3 cells exposed to grading concentrations of methanolic extract of $B$. racemosa bark, MEBR $(0-75 \mu \mathrm{g} / \mathrm{ml})$ as measured by DCFH-DA staining at $12 \mathrm{~h}$.

\section{DISCUSSION}

Prostate cancer is the most often diagnosed cancer and the second foremost cause of cancer death in Western males, the progression of which may be a consequence of defect in apoptotic machinery. ${ }^{2}$ Hence, antiproliferative effect of MEBR was investigated in present study on prostate cancer cell line by MTT assay and underlying mechanism of cancer prevention was elucidated by assessment of apoptosis induction.

Yellowish MT'T solution on reduction in metabolically active cells yields water insoluble purple colored needleshaped MT'T formazan crystals which get deposited as an extracellular deposit by exocytosis..$^{15}$ The amount of formazan increases with increase in number of viable cells while decreases with increase of cytotoxicity. ${ }^{16}$ Results of the study clearly demonstrated that MEBR exposure to PC3 cells significantly $(p<0.001)$ increased the cytotoxicity and decreased the amount of formazan in a concentration dependent manner. $\mathrm{IC}_{50}$ value was found to be $66.85 \mu \mathrm{g} / \mathrm{ml}$ of the extract MEBR.

Most of the cancer cells fail to undertake apoptosis due to mutilation of apoptosis. ${ }^{17}$ Inducing apoptosis in cancer cells can hence be an efficient approach in anticancer therapy. The cells undergo changes during the process of apoptosis characterized by plasma membrane blebbing, chromatin compaction, DNA fragmentation, cell shrinkage and collapse into small intact fragments called apoptotic bodies. ${ }^{18}$ Apoptosis increases the cell membrane permeability to DAPI, a DNA-specific dye that displays a blue fluorescence and thus leaves stronger blue fluorescence. ${ }^{19}$ Results of the study clearly demonstrated that MEBR induced significant $(p<0.001)$ nuclear condensation in a concentration dependent manner depicting the induction of apoptosis in PC3 cells. 
Anticancer and chemopreventive agents prompt cells to produce ROS which induce apoptosis. ${ }^{7,20}$ The DCFHDA passes the cell membrane, gets cleaved by intracellular esterases to DCFH and thereby trapped within the cells. DCFH gets oxidized to the fluorescent DCF (2,7-dichlorofluorescein) emitting bright fluorescence. ${ }^{21}$ Results of the study clearly demonstrated that MEBR elevated the significant ROS activity level and fluorescence intensity in a concentration dependent manner as compared to control in PC3 cells exposed to MEBR.

Phenolics and flavonoids are well known to have cytotoxic effect and induce apoptosis in various cancer cell lines due to their pro-oxidant property. ${ }^{22}$ Results of the study have demonstrated the presence of flavonoid in MEBR as $868 \mathrm{mg}$ QE/g dried extract. Hence, flavonoids present in MEBR may be responsible for the antiproliferative activity of the extract.

\section{CONCLUSION}

The present study shows a relationship between antiproliferative effect of MEBR and apoptotic induction and shows that the cytotoxicity was due to the induction of ROS mediated apoptosis. It confirmed the potential of MEBR in human prostate cancer and therefore, may be potentially precious for application in chemotherapeutic drug developments.

\section{ACKNOWLEDGEMENT}

Authors are thankful to Faculty of Pharmacy, Integral University, Lucknow and Department of Zoology, University of Lucknow to encourage by its research atmosphere and its all valuable supports.

\section{CONFLICT OF INTEREST}

The authors declare no conflict of interest.

\section{ABBREVIATIONS}

MEBR: Methanolic Extract of Baubinia racemosa Lam; MTT: Methyl-Thiazolyl-Tetrazolium; $\mathbf{N a N O}_{2}$ : Sodium Nitrite; $\mathbf{A l C l}_{3}$ : Aluminium Trichloride; $\mathbf{N a O H}$ : Sodium Hydroxide; PBS: Phosphate Buffered Saline; DAPI: 4',6-Diamidino-2-Phenylindole; ROS: Reactive Oxygen Species; DCFH-DA: 2,7-Dichlorodihydrofluorescein Diacetate; ANOVA: Analysis of Variance; QE/g: Quercetin Equivalent Per Gram; IC: Inhibitory Concentration.

\section{REFERENCES}

1. Jemal A, Siegel R, Ward E, Hao Y, Xu J, Thun MJ. Cancer statistics. CA Cancer J Clin. 2009;59(4):225-49.

2. Wen J, Li R, Wen X, et al. Dysregulation of cell cycle related genes and microRNAs distinguish the low- from high-risk of prostate cancer. Diagn Pathol. 2014;9(1):156.

3. Chen $\mathrm{H}$, Yen $\mathrm{G}$. Antioxidant activity and free radical-scavenging capacity of extracts from guava (Psidium guajava L.) leaves. Food Chem. 2007;101(2):686-94.

4. Suri RK, Chaudhari DC, Jaffer R. Commercially important medicinal plants from forest. J Ecol Bot Phytochem. 1992;3:129-40.

5. Gamble JS. The flora of the presidency of Madras. Botanical Survey of India (I), Calcutta, India. 1967.

6. Garodia P, Ichikawa H, Malani N, Sethi G, Aggarwal BB. From ancient medicine to modern medicine: Ayurvedic concepts of health and their role in inflammation and cancer. J Soc Integr Oncol. 2007;5(1):1-16.

7. Rahman MA, Kamal M, Hussain A, Arif M, Khushtar M. Phytochemistry and pharmacology of traditionally used tropical medicinal plant Bauhinia racemosa Lam. T Pharm Res. 2015;13(1):26-41.

8. Akhtar AH, Ahmad KU. Anti-ulcerogenic evaluation of the methanolic extracts of some indigenous medicinal plants of Pakistan in aspirin-ulcerated rats. $\mathrm{J}$ Ethnopharmacol. 1995;46(1):1-6.

9. Prakash A, Khosa RL. Chemical studies on Bauhinia racemosa. Curr Sci. 1976;45:705.

10. Alam J, Mujahid M, Badruddeen, Jahan Y, Bagga P, Rahman MA. Hepatoprotective potential of ethanolic extract of Aquilaria agallocha leaves against paracetamol induced hepatotoxicity in SD rats. J Tradit Complement Med. 2017;7(1):9-13.

11. Zhishen J, Mengcheng T, Jianming W. The determination of flavonoid contents in mulberry and their scavenging effects on superoxide radicals. Food Chem. 1999;64(4):555-9.

12. Rahman MA, Hussain A. Anticancer activity and apoptosis inducing effect of methanolic extract of Cordia dichotoma against human cancer cell line. Bangladesh J Pharmacol. 2015;10:27-34.

13. Rahman MA, Sahabjada AJ. Evaluation of anticancer activity of Cordia dichotoma leaves against a human prostate carcinoma cell line, PC3. J Trad Compl Med. 2017;7(3):315-21.

14. Rahman MA, Akhtar J, Sahabjada, Arshad M. Evaluation of cytotoxic potential and apoptotic effect of a methanolic extract of Bauhinia racemosa Lam against a human cancer cell line, HeLa. European J Integr Med. 2016;8(4):513-8.

15. Berridge MV, Tan AS, McCoy KD, Wang R. The biochemical and cellular basis of cell proliferation assays that use tetrazolium salts. Biochemica. 1996;4(1):14-9.

16. Van J, Kaspers GJ, Cloos J. Cell sensitivity assays: The MTT assay. Methods Mol Biol. 2011;731:237-45.

17. Hengartner MO. The biochemistry of apoptosis. Nature. 2000;407(6805):7706.

18. Borner $\mathrm{C}$. The Bcl2 protein family: Sensors and checkpoints for life-or-death decisions. Mol Immunol. 2003;39(11):615-47.

19. Bold RJ, Termuhlen PM, McConkey DJ. Apoptosis, cancer and cancer therapy. Surg Oncol. 1997;6(3):133-42.

20. Aggeli IK, Gaitanaki C, Beis I. Involvement of JNKs and p38 MAPK/MSK1 pathways in $\mathrm{H} 2 \mathrm{O} 2$-induced upregulation of heme oxygenase-1 mRNA in H9c2 cells. Cell Signall. 2006;18(10):1801-12.

21. Kim YM, Lim JM, Kim BC, Han S. Cu, Zn-superoxide dismutase is an intracellular catalyst for the $\mathrm{H}_{2} \mathrm{O}_{2}$ dependent oxidation of dichlorodihydrofluorescein. Mol Cells. 2006;21(1):161-5.

22. Prochazkova D, Bousova I, Wilhelmova N. Antioxidant and prooxidant properties of flavonoids. Fitoterapia. 2011;82(4):513-23. 


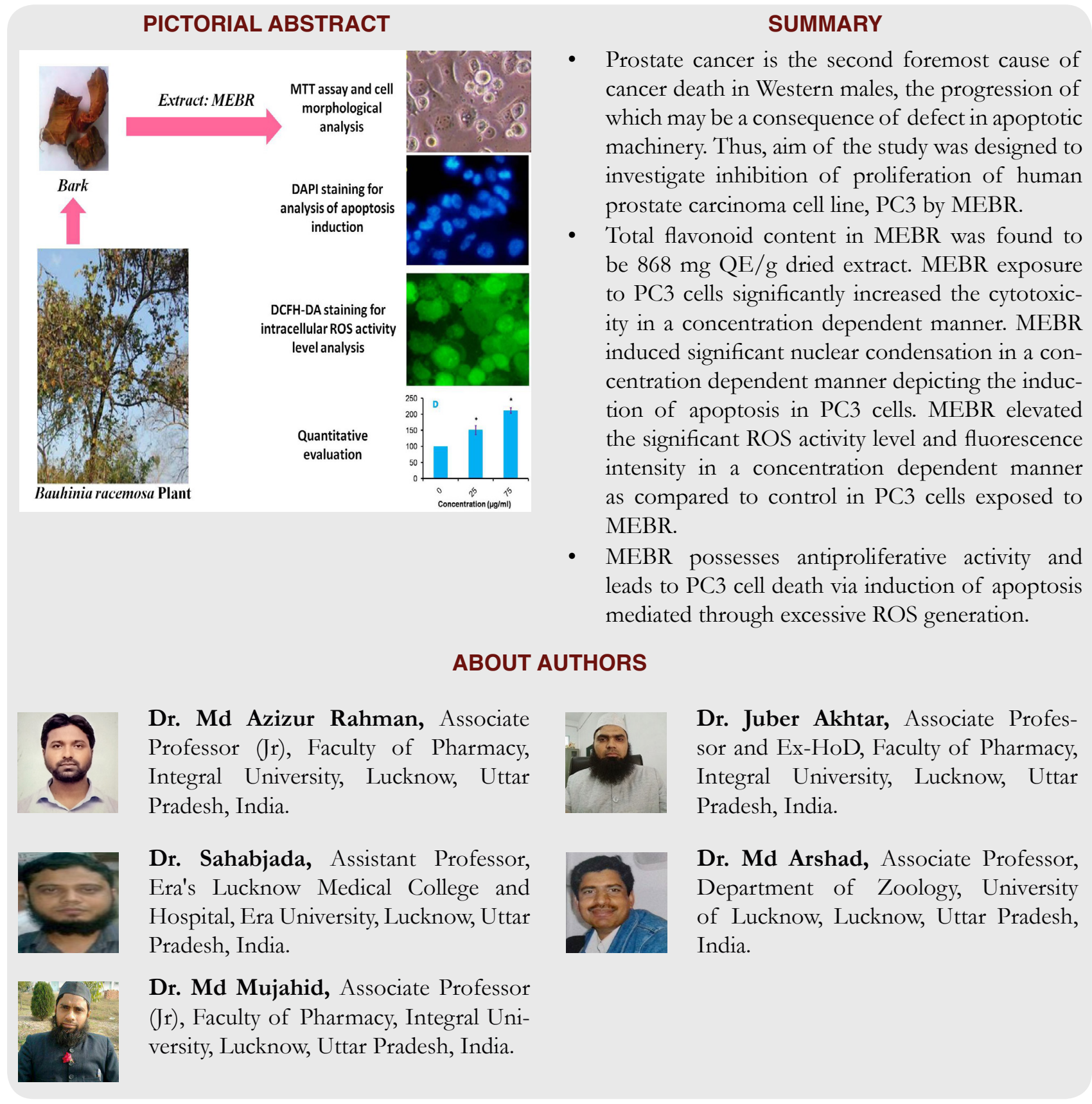

Cite this article: Rahman MA, Akhtar J, Sahabjada, Arshad M, Mujahid M. Inhibition of Proliferation of Human Prostate Carcinoma Cell, PC3 by Bauhinia racemosa Lam via Induction of Apoptosis. Indian J of Pharmaceutical Education and Research. 2019;53(3):521-26. 